\title{
Listening to the Voices of Grandparents Raising Primary-Grade Grandchildren Using a Qualitative Study
}

\author{
Seung-Min Song ${ }^{1}$, Woon Kyung Lee ${ }^{2}$, Yoon Hyung Lee ${ }^{3}$, Hyunah Kang ${ }^{4}$, \\ Eun Hye Kim², Hara Kang ${ }^{2}$ \\ Department of Child \& Family Welfare, The University of Suwon, Hwaseong, Korea ${ }^{1}$ \\ Department of Child Development \& Intervention, Ewha Womans University, Seoul, Korea ${ }^{2}$ \\ Early Childhood Education Major, Graduate School of Education, Seoul National University of \\ Education, Seoul, Korea ${ }^{3}$ \\ Division of Children's Welfare \& Studies, Sookmyung Women's University, Seoul, Korea ${ }^{4}$ \\ 조부모의 학령 초기 손자녀 대리양육 경험에 관한 질적 연구 \\ 송승민 ${ }^{1}$, 이운경 ${ }^{2}$, 이윤형 ${ }^{3}$, 강현아 ${ }^{4}$, 김은혜 ${ }^{2}$, 강하라 ${ }^{2}$ \\ 수원대학교 아동가족복지학과 ${ }^{1}$, 이화여자대학교 아동학과 ${ }^{2}$, 서울교육대학교 교육대학원 유아교육전공 ${ }^{3}$, \\ 숙명여자대학교 아동복지학부 ${ }^{4}$
}

Objective: The present study examined the perspectives of grandparents raising their grandchildren in an attempt to better understand grandparents' child-rearing experience while providing kinship foster care to their primary-grade grandchildren.

Methods: Data were collected through individual in-depth interviews with eight grandparents who have raised one or two primary-grade (ages $8-10$ ) grandchildren using a qualitative approach.

Results: First, the participants viewed the reason for their kinship foster care as a failure for caring for their own children and accepted the present grandparent-care provision as their responsibility. Second, the participants communicated constant struggles with their own health and grandchild-care as well as positive/negative emotions associated with the care provision. Third, most of the participants did not fully understand the developmental needs of their primarygrade grandchildren. Fourth, the participants articulated concerns for their primary-grade grandchildren's learning, peer interactions, school adjustment, and extra-curricular activities. Lastly, the participants all agreed on hoping to raise grandchildren with good personality traits as members of a society and to have them fill the gap from the loss of their parents.

Conclusion: Although most participants accepted the current circumstances as their obligation, they still noted difficulties in child-care provision. Given the developmental needs of grandchildren and the resource needs of grandparents, proper and continuous intervention approaches should be developed/provided.

Keywords: grandparents raising grandchildren, primary-grade, child-rearing experience, kinship foster care, qualitative research

Corresponding Author: Woon Kyung Lee, Department of Child Development \& Intervention, Ewha Womans University, 52, Ewhayeodaegil, Seodaemun-gu, Seoul, Korea

E-mail: lwk@ewha.ac.kr
(C)The Korean Association of Child Studies

This is an Open Access article distributed under the terms of the Creative Commons Attribution Non-Commercial License (http:// creativecommons.org/licenses/by-nc/4.0) which permits unrestricted noncommercial use, distribution, and reproduction in any medium, provided the original work is properly cited. 


\section{서론}

현대사회의 급격한 가족 형태 및 사회구조 변화에 따라 조부 모가 18세 이하의 손자녀와 거주하며 손자녀의 양육에 일차 적인 책임을 지는 조손가정(Song, 2013)은 해마다 빠르게 증 가하고 있다. 통계청의 장래가구추계조사에 따르면, 조손가구 는 2000 년에는 전체 가구의 $0.31 \%$ 인 45,398 가구, 2005 년에는 $0.36 \%$ 인 58,058 가구, 2010 년에는 $0.68 \%$ 인 118,527 가구에 해 당되는 것으로 나타나, 10 년 동안 $151 \%$ 증가하였다. 같은 기 간에 전체 가구 증가율이 $19.7 \%$ 였음을 감안할 때, 이러한 결 과는 조손가구의 비율이 급속도로 증가하고 있음을 보여주고 있으며, 2020 년에는 전체 가구의 $3.53 \%$ 정도가 조손가구일 것 으로 예측되고 있다(Statistics Korea, 2014). 조손가정의 급격한 증가에 따라 조손가정 내 조부모와 아동에 대한 사회적, 학문 적 관심 또한 지속적으로 증가되어 왔으나, 최근에는 조손가 정에 대한 명확한 개념적 정의의 필요성이 제기되고 있다(W. Kim \& Jeon, 2010). 그중에서도 부모의 맞벌이로 인한 양육 부 재의 경우와 부모세대의 해체로 인한 조손가정의 경우, 조부 모 및 아동의 발달에 미치는 영향은 크게 다르다고 보고되어 (J.-Y. Lee, Kim, \& Chung, 2009), 조손가정의 형태 및 그에 따 른 가정 내 경험에 대한 명확한 이해의 필요성이 제기된다.

조손가정 중에서도 현행 아동복지법 제 2 조에 의하여 부모 의 질병, 가출, 실직, 수감, 사망 및 그 밖의 사유로 인해 보호가 필요하다고 인정된 아동을 친조부모 또는 외조부모가 가정 위 탁의 형태로 양육하며 정부 차원의 지원을 받는 경우는 대리 양육이라고 정의된다(S. K. Kim, Kim, \& Choi, 2009). 가족의 해체와 불안정이 가속화되는 과정에서 요보호 아동은 늘어나 고 시설보다는 가정과 유사한 환경의 가정위탁에 대한 정책적 선호가 강조되면서 가정위탁의 비율은 증가해 왔다 (Statistics Korea, 2014). 특히 보호가 필요한 아동을 낮선 이가 돌봐주는 것 보다는 혈연관계인 조부모를 통해 가족적인 보호 환경을 제공하는 것이 부모의 부재로 인한 아동의 심리사회적인 부적 응을 완화시키는 방안이라 인식된다. 이에 따라, 조부모가 위 탁 부모가 되어 아동을 돌보는 형태가 위탁가정 중에서 가장 높은 비율을 차지한다(W. Kim \& Jeon, 2010).

이러한 위탁형태를 우리나라에서는 '대리위탁가정'이라고 부르는데, 이러한 조부모의 손자녀 돌봄은 조부모들의 신체 적, 심리적 쇠약과, 사회적인 고립, 경제적인 어려움 등 다양 한 범위에서 문제를 야기하고 있다(N.-R. Bae \& Park, 2013). 무엇보다도 조부모가 손자녀 양육으로 인한 신체적인 고통 을 호소하는 경우가 다수 보고되고 있는데(Bachman \& Chase-
Lansdale, 2005; Neely-Barnes, Graff, \& Washington, 2010), 조부 모가 되는 연령이 일반적으로 중년기 후반 또는 노년기이므로 체력이 저하된 상태에서 양육의 부담을 안게 되어 건강문제 가 초래되는 경우가 많다(Kwon, 2000; C.-K. Park, 2002). 실제 로 조부모 양육자들의 절반정도가 건강에 심각한 영향을 미치 는 신체적인 문제와 질병이 있다고 보고하고 있다(H.-K. Choi, 2006). 좋지 않은 건강상태는 양육스트레스의 증가(Sands \& Goldberg-Glen, 2000) 및 우울감의 경험(Kwon, 2000)과도 관련 된다.

대리양육 중인 조부모는 신체적 요인 외에도 다양한 가정 내, 가정외 요인들로 인해 우울감 및 스트레스를 경험할 가능 성이 높다. 손자녀와의 관계에서의 어려움을 경험하거나(J.H. Bae, 2007), 손자녀에 대한 올바른 양육방법을 몰라 손자녀 에 대한 대리 부모역할을 잘 하고 있는지 불안할 때(H.-S. Kim, 2009; Seo \& Kim, 2010), 사회적인 지지를 받을 상황이 되지 못 할 때(O.-N. Kim, 2007), 조부모의 우울감은 높아진다. 손자녀 양육으로 인한 대리양육 조부모의 경제적 어려움 또한 보고된 다. 손자녀 양육으로 인해 조부모는 노후의 삶에 대한 자기 부 양과 손자녀의 부양이라는 이중 부담을 감당하게 되는데, 조 기퇴직이라는 사회구조적 현실과 신체적 어려움으로 인한 의 료비용, 노후 대책의 필요성 등(M.-Y. Lee, 2007; Ok, 2005)은 경제적 상황을 더욱 악화시킨다. 이러한 조부모의 열악한 경 제수준은 다시 조부모의 스트레스나 우울감에 영향을 미칠 가 능성이 있다(Kwon, 2000).

그러나 다양한 어려움에도 불구하고 최근의 연구들은 손 자녀 양육과정이 조부모에게 긍정적인 영향을 미친다는 결 과 또한 보고하고 있어 조부모의 손자녀 대리양육 경험의 다 양한 측면들을 이해할 필요성을 제기하고 있다. 노년기에 새 로이 얻게 되는 역할로 인해 손자녀 양육이 살아갈 목표가 되 며(Ministry of Gender Equality \& Family, 2007), 조부모로서 존 재의 필요성을 인식할 수 있다고 보고된다(N.-R. Bae \& Park, 2013). 또한 손자녀의 바람직한 성장을 통해 즐거움, 만족감, 심리적 보상감을 느끼며(Cox, 2009; K.-A. Park, 2007), 이러한 조부모들의 긍정적인 심리적 경험은 손자녀의 발달에 긍정적 인 영향을 미친다(Brian, 2000).

이와 같이 선행연구들은 손자녀를 양육 중인 조부모들의 다양한 부정적, 긍정적 경험을 보고하고 있다. 그러나 현재까 지 축적된 연구들은 대다수 조부모가 경험하는 신체적, 심리. 사회적, 경제적 측면의 일부분에 단편적으로 초점을 맞추어 왔다(H. Choi, 2006; Jang \& Kim, 2008). 또한 국외의 경우 급 격한 사회변동과 가족 해체의 증가로 인해 손자녀를 양육하 
는 조부모들의 관한 연구들이 90 년대 초부터 본격적으로 이 루어진 반면(Burnette, 2000; Fuller-Thomson, Minkler, \& Driver, 1997; Ross \& Aday, 2006), 국내의 경우 가정위탁보호에 대한 법적 근거가 마련된 이후인 1999년 이후에야 관련 연구가 대 부분 수행되어(S. K. Kim et al., 2009; W. Kim \& Jeon, 2010), 아 직까지 대리위탁가정 내의 경험을 충분히 통합적으로 이해하 기에 어려운 실정이다. 무엇보다도 선행 연구들은 대리위탁가 정을 일시적 보호형태로 간주하여, 손자녀의 기본적인 욕구를 충족시키는 보호적 기능의 양육에 초점을 두고 접근한 경우가 많아(M. Y. Kim \& Yoon, 2015), 손자녀의 전인적인 발달을 돕 는 양육자로서의 조부모 대리양육 경험에 대한 이해가 충분하 지 않다는 한계점을 지닌다. 물론 가정위탁의 본래 취지는 일 시적 보호를 제공하고 궁극적으로 친가정 복귀를 목표로 하 지만 우리나라의 현실에서 특히 대리위탁가정에서 아동이 보 호양육되는 기간은 평균 8년 이상으로 매우 장기화되고 있다 (Kang, Chung, Chun, Nho, \& Woo, 2014).

한편 조부모가 대리양육하고 있는 손자녀의 발달적 측면을 고려해보았을 때, 특히 학령 초기를 포함하는 8-11세 아동은 국내 위탁 아동 중 가장 높은 비율( $40 \%)$ 을 차지함에도 불구하 고(Ministry of Health \& Welfare [MOHW], 2013), 지금까지 대 리위탁가정 조부모들에 관한 연구들은 영유아기와 같이 학령 기 이전의 더 어린 연령층의 손자녀를 둔 조부모를 대상으로 하거나(Kwon, 2000), 만 18세-20세 미만에 해당하는 광범위한 연령층의 손자녀를 양육하는 조부모를 대상으로 대부분 시행 되었다(Y.-M. Kim, Kim, \& Jung, 2008; M.-Y. Lee, 2008). 그러 나 특히 학령 초기는 아동이 공교육 과정에 진입하며 또래관 계의 확장, 교육 과정 내의 다양한 과제 등 여러 가지 도전에 직면하는 중요한 시기로서(Doh, Lee, Kim, Choi, \& Lee, 2011), 양육자 또한 아동의 변화된 발달 단계에 맞춰 새로운 양육 방 법을 사용하고, 아동의 학교생활 및 확대된 대인관계에서 발 생하는 다양한 문제들을 해결하도록 돕는 역할을 수행하면서 역할 긴장과 스트레스를 경험하기 쉬운 시기이다(Ha \& Jang, 2010; S. J. Kim et al., 2015). 이와 관련하여, 부모의 학령 초기 아동 양육경험에 대한 연구결과들은 소수 보고되었으나(Doh et al., 2016; S. J. Kim et al., 2015; Nomaguchi, 2012), 학령 초기 아동의 적응 및 양육자의 역할의 중요성에도 불구하고 학령 초기 손자녀를 양육하는 조부모를 대상으로 아동의 양육 경험 에 관해 살펴본 국내외 연구는 거의 전무한 실정이다. 즉, 양육 경험을 이해하는 데 있어 아동의 발달 단계에 따른 양육자 역 할 및 적응을 고려하는 것이 매우 중요함에도 불구하고, 선행 연구들은 조부모로서의 경험을 살펴보는 데 있어 손자녀 발달
단계 특성에 따른 양육자 역할에 대한 고려가 매우 부족하였다 고 볼 수 있다. 따라서 본 연구에서 학령 초기 손자녀를 둔 조부 모를 중심으로 대리양육 경험을 살펴볼 필요성이 강조된다.

또한 대리위탁가정 또는 조손가정 내 조부모에 관한 선행 연구들의 대다수는 양적 연구로 수행되었으며 질적 연구는 아 직 상대적으로 적은 편이다. 그러나 양적 연구와 질적 연구의 결과를 통합적으로 조명함으로서 대상에 대한 이해는 극대화 된다는 관점에서(Maxwell, 2005), 대리위탁가정 내 조부모에 대한 질적 접근이 필요하다. 특히 조부모의 시각에서 손자녀 대리양육 경험을 살펴보는 질적 연구는 조부모가 갖고 있는 양육자로서의 태도, 아동 양육의 긍정적/부정적 측면, 양육 환 경 및 정서적 경험에 대한 인식 등 조부모에게 인식되는 대리 양육의 다양한 측면을 심층적으로 이해하는 데 중요한 역할을 할 수 있다. 이는 나아가 대리위탁가정에 실제적으로 개입하 기 위한 중요한 지식적 기반이 될 것이다.

요약하자면, 본 연구는 대리위탁가정에서 학령 초기 손자 녀를 대리양육 중인 조부모들의 양육경험을 심층적으로 이해 하기 위해 조부모의 시각에서 손자녀 양육경험을 살펴보고자 한다. 보다 구체적으로, 조부모들이 손자녀 양육에 대해 어떻 게 인식하고 표현하며, 경험하는지에 대한 이해를 통해 조부 모의 대리양육 경험을 심층적으로 조명하고자 한다.

\section{연구문제}

조부모가 학령 초기 손자녀를 대리양육하는 과정에서 보고하 는 양육경험은 어떠한가?

1-1. 조부모가 학령 초기 손자녀를 대리양육하는 과정에서 보고하는 양육에 대한 태도는 어떠한가?

1-2. 조부모가 학령 초기 손자녀를 대리양육하는 과정에서 보고하는 양육자로서의 경험은 어떠한가?

1-3. 조부모가 학령 초기 손자녀를 대리양육하는 과정에서 보고하는 대리양육에 대한 인식 및 요구는 어떠한가?

\section{연구방법}

\section{연구 참여자}

본 연구의 참여자는 경기도, 서울특별시 및 인천광역시 지역 
에 거주하고 있으며, 현재 학령 초기에 해당하는 손자녀(8세 $\sim 10$ 세)를 적어도 1 명 이상 대리양육 하고 있는 조모 여덟 명 이다. 연구대상자 선정의 적절성 및 정보의 충분성을 위하여 질적 연구에서 주로 사용되는 의도적 표집 방법을 사용하였으 며(Patton, 2002), 학령 초기 손자녀 양육이라는 동질성을 기초 로 한, 대리양육의 전형적 사례가 연구대상으로 선정되었다. 연구대상자 선정을 위해 경기지역 가정위탁지원센터를 통하 여, 센터의 지원을 받는 대리양육 중인 조부모에게 본 연구의 목적과 취지를 알리고, 학령 초기 손자녀를 1 년 이상 대리양육 한 조모 중, 연구에 참여하기 원하는 대상자 총 8 명을 모집하 였다.

연구 참여자들의 특성을 살펴보면, 연령 범위는 60-80세로 서, 평균연령은 67.38 세 $(S D=6.59)$ 였다. 건설 일용직과 식당 일용직으로 근무하고 있는 두 명의 연구 참여자를 제외하고 나머지 연구 참여자는 전업주부였다. 대리양육의 기간은 2 년 9년의 분포를 보였으며, 2 년 동안 손자녀를 양육한 한 명의 조모를 제외하고, 나머지 연구 참여자들은 1 차 개별면접 시점 기준으로 모두 6년 이상 손자녀를 양육하고 있었다. 한 명의 손자녀를 키우고 있는 조모는 5명, 두 명의 손자녀 이상을 양 육하고 있는 조모는 3 명이었다. 손자녀의 성별을 포함한 연구 참여자의 일반적인 특성은 Table 1에 제시되어 있다.

\section{자료수집 및 조사절차}

본 연구의 자료 수집을 위해 참여자 당 총 두 차례의 심층 개 별 면접을 실시하였다. 가정위탁지원센터를 통해 연구 참여에
동의한 연구대상자에게 전화를 통해 면접 시간 및 장소를 선 정하였으며, 연구 참여자들의 편의를 위하여 면접 장소는 주 로 참여자들의 자택이나 자택 주변의 조용한 장소를 이용하였 다. 1차 개별면접은 2016년 3월 14일부터 2016년 3월 21일까 지 실시하였고, 면접은 2 명의 박사급 연구원과 2 명의 박사 과 정생에 의해 실시되었다. 참여자 별로 총 90-120분가량의 면 접이 진행되었으며, 각 면접별로 1 명의 면접자 외에 1 명 내지 2 명의 진행자가 동석하여 관찰노트를 작성하였다. 추가적인 자료 수집을 위한 2차 개별 면접은 2016년 6월 7일부터 2016 년 7월 9일까지 진행되었고 면접자 1 명과 연구 참여자 간 총 30-90분가량의 전화통화를 통해 시행하였다.

1 차와 2차 개별 면접은 모두 반구조화(semi-structured)식 면 담으로 이루어졌다. 연구자들은 사전에 조부모됨의 경험을 심 층적으로 탐색하기 위한 구조화된 형태의 질문들을 준비하였 고, 면접 중에 적절하지 않다고 판단되는 경우에는 연관되는 대안적인 질문들을 활용하며 개별 면접을 진행하였다. 질문준 비 및 면접 실시 과정에서 연구자들은 오프라인 및 온라인으 로 지속적으로 의견을 교환하였다. 1 차 개별면접을 위해 연구 자가 제시한 질문들의 범주는 다음과 같다. 첫째, 참여자의 기 본 정보, 둘째, 양육자로서 조부모됨에 대해 대상자가 가지고 있는 생각, 셋째, 대상자가 생각하는 양육자로서 바람직한 조 부모상(양육신념), 넷째, 학령기 손자녀의 자녀양육과 관련된 대상자의 양육방식과 양육경험, 다섯째, 손자녀를 기르면서 느끼는 양육 스트레스에 대해 질문하였고, 참여자는 이에 자 유롭게 응답하였다. 2 차 개별면접에서는 1 차 개별면접 이후 한 학기동안 추가적으로 학령 초기 아동을 양육하면서 경험한

Table 1

General Characteristics of Participants

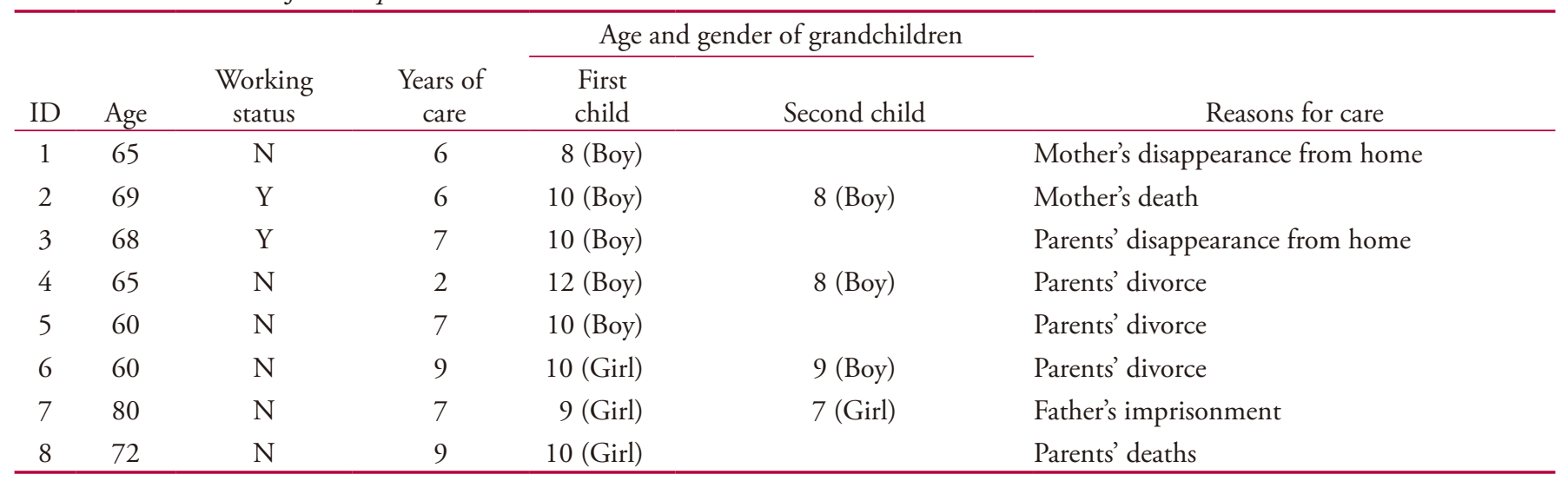

Note. $N=8 . \mathrm{Y} / \mathrm{N}=$ working/not working. 
조부모로서의 양육경험을 질문하였다. 손자녀의 학교생활 및 방과 후 지도, 학령 초기 손자녀의 필요에 대한 인식, 조모의 학교 참여 및 교사와의 관계 경험에 관한 집중적인 면접이 이 루어졌다. 두 차례의 면접을 진행하며 연구자들은 연구 참여 자에 대한 관찰을 병행하였고, 기록할만한 비언어적 행동 및 면접 과정에서 손자녀와의 상호작용이 있을 때는, 분석 시 연 구자의 생각을 발전시킬 수 있도록 메모를 작성하였다(Glaser $\&$ Strauss, 1967). 두 차례의 개별 면접은 연구 참여자의 동의하 에 녹음된 후, 분석을 위하여 전사되었으며, 연구 참여자별 전 사 자료는 1차와 2차 면접을 모두 합하여 A4용지 28-33쪽 분 량이었다.

\section{자료 분석}

본 연구는 손자녀를 대리양육하는 조부모의 경험 및 그 의미 를 심층적으로 이해하기 위함이며, 나아가 선행연구와 더불 어 손자녀 대리양육을 돕기 위한 실제적인 지원 방향 모색에 그 의의를 두고 있다. 이를 위해 연구참여자의 '경험'을 가장 잘 드러내주는 면담법을 도입하였다. 질적 연구법에서의 면담 법은 경험 속에 내재된 상세한 과정 안에서의 일련의 사건들 을 선택하며, 사건을 곰곰히 되돌아보게 하며, 그 사건들에 특 별한 의미를 부여하는 과정을 거친 '의미 구성'된 경험을 연구 한다(Seidman, 1998). 이렇게 재구성된 경험은 연구자에게 언 어라는 매개로 전달되는 과정을 거친 결과물이다. 따라서 심 층면담법은 사람의 경험과 그 경험의 의미를 이해하는 데에 가장 적절한 방법이라고 할 수 있겠다.

수집된 자료 분석을 위해 Miles와 Huberman (1994)이 제 시한 3 단계의 분석과정을 거쳤다. 그 첫 번째 단계는 자료 축 소 단계(data reduction)로 전사 자료들을 반복해서 읽고 선택, 집중, 단순화의 과정을 통해서 참여자들이 표현하고자 한 중 심 의미를 도출해내었다. 두 번째 단계는 자료 열거 단계(data display)로 앞서 도출된 중심 의미들 중에서 서로 관계가 있는 것들끼리 유목화 및 조직화 하였다. 마지막 단계는 결론 도출 및 확인 단계(conclusion drawing \& verification)로 자료들을 반 복해서 읽고 살펴보며 분석된 데이터의 의미를 검토하고, 유 목화 및 조직화된 중심 의미들의 타당성을 확인하는 과정이었 다. 이와 같은 과정을 통해 양적 연구 방법으로는 분석하기어 려운, 연구 참여자들의 경험을 이루는 정서적, 인지적, 행동적 측면의 심층적 현상들 및 이들의 상호관계를 이들이 처한 맥 락 안에서 분석하고자 하였다. 분석 과정에서는 질적 자료 분 석 프로그램인 MAXQDA 12 (VERBI GmbH, Berlin, Germany)
가 활용되었다.

\section{연구의 타당성, 신뢰성 및 윤리적 고려}

본 연구에서는 결과의 타당성을 확보하기 위해서 Creswell과 Miller (2000)가 제시하였던 전략들 중 동료 검토(peer review or debrifing), 연구 참여자 확인(member check)을 시행하였다. 동 료 검토를 위해 공동연구자들 외에 질적 연구경험이 풍부한 교수 1 인과 본 연구의 연구방법과 의미, 해석에 대해 논의하는 과정을 거쳤다. 연구자는 면접내용을 외부자의 중립적인 시각 에서 바라보며 분석하는 과정을 포함하는 동시에, 연구 참여 자 확인을 위해 2 차 개별면접 시에 1 차 개별 면접 결과의 내용 을 면접자와 구두로 확인하였다.

면접자는 연구 참여자의 권리를 보호하기 위하여, 개별면 접 전에 연구목적 및 절차, 자료의 활용 및 비밀보장의 내용이 명시된 연구 동의서를 제시하고 설명하였으며, 연구 참여자의 동의가 있은 후, 면접자 및 연구 참여자의 서명을 포함한 2 부 의 연구동의서를 작성하여 면접자와 연구 참여자가 각각 1 부 씩 보관하도록 하였다. 녹음자료의 전사자들은 전사 작업 전, 전사 작업의 내용이나 대상자의 정보 등을 외부로 유출하지 않겠다는 서약서를 작성하였으며, 면접자는 전사가 이루어진 후 녹음 내용과 전사된 내용이 각각 일치되는지 확인하였다. 연구 참여자의 익명성을 보장하기 위하여, 자료수집 및 분석 과정에서 연구 참여자에게 고유 대체 번호를 부여하였다.

\section{연구결과}

\section{대리양육에 대한 태도}

\section{대리양육에 대한 초기 태도}

본 연구에 참가한 대부분의 조모들은 손자녀를 대리양육하게 된 상황에 대하여, 본인이 자녀들을 바람직하게 양육하지 못 하였기 때문에 맞닥뜨리게 된 어쩔 수 없는 상황으로 받아들 이고 있었다. 손자녀를 양육하는 책임은 이들에게 '짐'과 같이 무겁게 다가왔지만, 자녀에게 문제가 발생하여 손자녀 대리양 육을 하게 된 상황을 적어도 일부분 자신의 잘못에 기인한 것 으로 인식하고 있었으며, 손자녀를 양육하게 된 상황을 자신 의 ‘운명,' ‘업보’ 등으로 표현하며 수용하고 있었다. 
그 때는... 받아들일 때는, 내가 내 자식을 제대로 못 키웠 으니까. 내 운명이다 생각하고 그냥. 내가 짊어지고 가야 할 짐이잖아요. 한마디로 말하자면 자식을 못 키웠으니 까. 제대로 못 키웠으니까. 건사를 못했으니까 애가 이제 나한테 온 것 같다. 그렇게 생각을 하는 거죠. (1차 개별 면접, ID 01)

딸래미들한테도 좀 더 잘해주고 신경을 쓰고 했으면 이 런 저기까지는 안 오고... 내가 좀 더 신경을 쓰고 그랬으 면 이런 상황까지는 안됐을 텐데, 그런 후회를 좀 많이 하는 편이예요. (1차 개별면접, ID 05)

남편이랑 항상 그래서 그냥 내 죄인가 보다 싶어서 애들 을 즐거운 마음으로 키우려고 그래. 그건 내가 지은 죄 다... 그때는 조금 안 좋았어요. 사는 것도, 부부간에도 힘 들고. 그때는 남편이랑 서로 헤어지니 어쩌니 그래서. 손 자 손녀를 내 업보다 하고 내 자식이다 하고 키우는 거 야. 아들을 못 키웠으니 애들을 내 손으로 키우라고 하나 님이 하시나보다 생각하고 키우는 거야. (1차 개별면접, ID 06)

\section{대리양육 경험 후의 태도 변화}

대리양육을 최소 2 년 이상, 최대 9년 이하의 기간 동안 지속한 개별면접 시점에서는 대부분의 연구참여자들이 대리양육 경 험의 긍정적인 측면을 인식하고 있었다. 연구참여자 본인의 자녀를 양육했던 경험과 비교하여 손자녀에게 더욱 많은 애정 을 느끼고 있다고 표현하였으며, 손자녀를 양육하고 있는 현 재의 경험을 소중하게 생각하였다.

확실히 내가 애들 키울 때는 솔직히 예쁜 것도 모르고 내 새끼 키울 때는 자기 바쁘니까 몰랐는데, 더 예뻐. (1차 개별면접, ID 02)

제가 일찍 결혼했어요. 그래서 일찍 애를 낳아서 애 낳고 직장 생활을 막 하다 보니까 애 이쁜지 어쩐지를 모르고. (중략) (손자녀가) 이쁘죠. 이쁘고 뭐든 하는 것 보면 더 해주고 싶고. (1차 개별면접, ID 05)

그 전에는 내 새끼는 키우는가보다 하고 키웠지. 이렇게 귀엽고 그런건 모르고. 그렇게 키웠는데 이것들은 하는
거 보면 너무 어떨 때는 귀엽고 예쁜 거예요. (1차 개별면 접, ID 06)

그러나 대리양육을 받아들이는 연구참여자의 자세에 영향 을 미치는 맥락 또한 확인할 수 있었다. 특히 본인의 자녀가 아 닌, 자녀의 배우자 잘못으로 손자녀를 대리양육하게 되었다고 인식하고 있는 연구참여자 두 명(ID 04, ID 07)은 의도치 않게 대리양육의 책임을 갖게 된 스트레스와 우울감을 1,2 차 개별면 접에서 지속적으로 보고하였다. 이들은 손자녀를 양육하는 것 이 본인의 성격특성에 적합하지 않다고 인식하며, 대리양육이 건강과 경제적 여건을 고려했을 때 부담스럽게 느껴진다고 설 명하였다. 특히 ID 04 연구참여자의 경우, 지속되는 부담감을 표현하며 2차 개별면접 시 대리양육을 중단할 결심을 밝혔다.

저 같은 경우에도 원래 나는 애들을 좋아하지 않아요. 막 애들 시끄러운 것도 싫어하고 애들이 막 버릇없이 구는 것도 싫어하고. (중략) 그러다가 이제 나이 먹어서 갑자 기 머슴아 둘이를 갖다가 딱 맡겼는데 얼마나 힘이 드는 지. (1차 개별면접, ID 04)

도대체 도저히 안 되겠어요. 나는 지금. (중략) 이랬든 저 랬든 애가 뭐 한국 애도 미국 애도 아니고. 그렇다고 여 기서 뭐 고등학교까지 다닐 수 있는... 그렇게 되면 되는 데, 그렇게까지도 내가 너무 힘들고. 여러 가지로 부담스 럽기도 하고. 이래서 그냥 (아이들이 아버지에게) 가야 되겠다... (2차 개별면접, ID 04)

\section{대리양육과 삶의 명암}

\section{대리양육과 연관된 고통}

건강의 한계 및 기초적 돌봄의 어려움 모든 연구참여자들은 건강상의 어려움을 표현하였고, 상당수는 건강의 한계가 학령 초기 손자녀를 양육하는데 있어서 걸림돌이 된다고 인식하고 있었다. 건강에 있어서 문제를 갖고 있는 것은 빨래, 청소와 같 은 가사를 수행하기 위한 신체적인 능력에 한계를 느끼는 것 뿐 아니라, 양육 스트레스를 많이 느끼는 것과도 밀접한 관련 이 있었으며, 나아가 손자녀가 충분히 성장하기까지 돌볼 수 있을지 염려하며, 양육에 필요한 건강을 희망하는 마음과도 연결되었다. 
빨래가 많잖아요. 빨래도 많고 해야 하는데 그럴 때는 어 쩔 때는 치우다보면 속상해서 성질이 나고 그러더라고. (중략) 왜냐면 일어섰다 앉았다하기가 작년까지도 좀 덜 했는데, 올해는 더 아프더라고요. 그래서는 아주 앉았다 일어났다 하는 게 너무 힘들어요. (1차 개별면접, ID 07)

쉽게 피로해져요. 조금 괜찮다가도 어디 다녀오고 하면 금방 피곤해져요. 힘들어요. 이제 내가 그런데 가도 항상 내가 못가니까 삼촌이 따라가고 그러죠. 지금은 항상 기 도 제목이 애들 클 때까지만 건강하게 해달라고. 20살에 서 25살만 넘어도 지들이 알아서 하니까 그 때 까지만 이 라도 건강하게 해달라고. 요즘 그게 기도 제목이에요. (1 차 개별면접, ID 06)

연구참여자들은 건강의 한계를 느끼는 가운데 손자녀들에 게 음식을 제공하거나 위생 상태를 관리하는 것과 같은 기초 적인 돌봄을 제공해야 하는 것에도 어려움을 경험하고 있었 다. 조부모로서 아이들의 기본적인 필요를 부모만큼 잘 채워 주지 못한다는 아쉬움을 느끼기도 하였고, 돌봄을 실제로 수 행하는 과정에서 손자녀를 양육하기 위한 적절한 방법을 잘 알지 못하는 것에 대한 스트레스를 경험하고 있었다.

애는 먹는 것도 그렇고 돌봐주어야 되니까. 지가 막 먹는 스타일도 아니고. 신시대에 먹는 것은..좀 내가 하기가 어려워서 내 먹는 식으로 해주고 이러니까 지가 먹는 게 만족하지 못하지. 우리 먹는 대로 하고 해줘도 저는 젊은 사람들 먹는 입장에서 먹질 못하니까 좀 그렇죠. 그런 거 예요. 애 먹이는 거 뭐 어떻게 해서 먹어야 할까 그게 걱 정이구. (1차 개별면접, ID 03)

대리양육 상황으로 인한 심리적 어려움 연구참여자들은 대리 양육 상황 하에서 다양한 이유로 발생되는 심리적 어려움 및 삶의 만족도 저하를 표현하였다. 대리양육의 부담을 지속적 으로 표현한 ID 04, ID 07 연구참여자의 경우 외에도, 대리양 육 이전의 가정사로 인한 심리적 고통을 지속적으로 경험하고 있는 것, 손자녀가 부모와 함께 살지 못하는 것, 또는 손자녀의 미래에 대해 걱정하는 것은 연구참여자들이 화병, 스트레스, 또는 우울함을 겪고 있다고 표현하는 것과 연관되어 있었다. 즉, 연구참여자들의 심리적 어려움에는 현재적 상황 뿐 아니 라 과거의 가족 내 경험 및 미래에 대한 예측 또한 영향을 미치 는 것으로 해석된다.
우리 손주 아버지 만나서 같이 잘 살아가면, 그런 거로 충당되면 50\% 만족도 되겠지. 더 아프지 않고 애들 살아 가는 거 보면서 살아가면 $50 \%$ 채워지겠지. (1차 개별면 접, ID 03)

그러니까 이제 내가 없으면 저걸 누가 데리고 키우나. 저 걸 저 이모가 갖다 키우나. 외삼촌이 갖다 키우나. 그게 걱정인 거예요. 저 고모들은 절대 안 키워요. 그 사람들 은 절대 안 키워요. 그러니까 그게 걱정인거예요. (1차 개 별면접, ID 08)

대리양육으로 인해 본인 자녀와의 관계 또한 악화되어 심 리적 고통을 겪고 있는 경우는 많지 않았지만 두 명의 참여자 에게서 볼 수 있었다. 두 명의 참여자들은 각각 자녀로 인해 발 생한 문제 상황들 때문에 지속적으로 분노하게 되는 상황과, 자녀라 할지라도 지속적인 실망감으로 인해 인연을 끊게 되는 마음에 대해 설명하였다.

○○엄마는 나한테 맞기도 많이 맞았어요. 얼마 전에도 화딱지가 확 나니까 쫓아가서 때리고 막 그러는데 그렇 게 좋은 저기는 아니에요. (1차 개별면접, ID 05)

제가 자식이라고 해도 너무 그러니까. 완전 인연을 끓어 버리는 거에요. 제가 인연을 끊어버리는 거예요. (중략) 어느 정도 질렸으니까. (1차 개별면접, ID 01)

\section{대리양육으로 인한 보상}

연구참여자들은 모두 대리양육과 연관된 다양한 어려움을 표 현하였지만, 손자녀를 양육하게 되면서 얻고 있는 보상 또한 인식하고 있었다. 무엇보다도 어린 손자녀를 양육하면서 경험 하는 즐거움과 손자녀로부터의 사랑, 양육의 보람은 대리양육 의 긍정적 측면으로 인식되고 있었다.

기쁨과 보람의 원천이 되는 손자녀 연구참여자들은 애정을 갖고 있는 대상인 손자녀와 함께 즐거운 시간을 갖는 것이 노 년기 생활의 ‘활력소’가 되고 있다고 인식하고 있었다. 또한 손 자녀가 조부모에게 표현하는 애정과 감사함의 표현이 기쁨이 됨을 경험하고 있었다. 특히 대부분의 조부모들은 자신의 자 녀를 키우던 젊은 시절에는 생활에 바빠서 충분히 경험하지 못했던 부모됨의 기쁨과 보람을 손자녀를 양육하면서 경험하 
고 있었다.

음악 쪽에도 지금 나오는 노래를 저는 모르는데, 자기가 그거를 배워가지고 댄스 같은 것 추고 막 그래요. 그리고 핸드폰에다 녹음을 해가지고 자기 노래를 담아가지고. 자기 노래를 녹음해가지고 들려주는 거예요. 그러면서 춤을 추는 거예요 이제. 그렇게 하고 있는데 화 낼 수는 없잖아요, 또. 식구들이. 식구들 이래봐야 셋이지만 화 낼 수가 없잖아요. 그러니까 웃는 거예요. (1차 개별면접, ID 01)

아무래도 활력소죠 아무래도. 노부부가 살면 무슨 재미 가 있겠어. 왔어 갔어 그러면 되는데 그래도 그게 있음으 로써 화가 나도 아이가 있음으로써 화가 날 땐 나고 주절 거릴 땐 또 예쁘고 그게 좋은 거지 뭐. 활력소예요. (1차 개별면접, ID 03)

그냥 항상 즐거운 것 같아요. 애들 생각하면 항상 즐거 워. 나한테 항상 우리 이렇게 키워줘서 고맙다고 편지도 자주 써주고 잘해줘. (1차 개별면접, ID 06)

또한, 결과적으로 손자녀가 큰 문제없이 발달하고 있는 모 습을 보는 것은 조부모의 보람이 되고 있었다. 예상치 못한 아 들 부부의 이혼으로 두 손자녀를 양육하고 있는 ID 04 연구참 여자의 경우에도, 비록 손자녀 양육을 하게 될 것을 예측하지 못하였고, 그로 인한 스트레스를 겪고 있음에도 불구하고, 손 자녀에게 양육자로서의 역할을 해주며 직장으로 인해 아이들 을 직접 돌볼 수 없는 아들에게도 도움이 되고 있음을 인지하 고 보람을 느끼고 있었다. 비록 모든 연구 참여자들이 대리양 육과 관련된 정서적 고통을 토로하고 있지만, 손자녀에게 결 핍된 양육자 역할을 해줄 수 있다는 사실은 대리양육의 중요 한 긍정적인 측면으로 여겨지고 있는 것으로 보인다.

어린이 집에서 졸업식 할 때도 애가 그렇게 밝고 애들하 고 사교성 있게 지내고. 누구하고 싸우거나 이런 적이 없 이 잘 커주고 하니까 그게 좋은 거예요. 아까도 말씀드렸 지만 아직까지는 병원에 입원하거나 그런 적이 없이 무 탈하게 큰 거나 마찬가지잖아요 지금. 감기 오는 정도니 까. 무탈한 거죠. 그렇게 커준 게 고마운 거죠. (1차 개별 면접, ID 01)

그래도 보람이 전혀 없는 건 아니니까 내가 좀 고생은 되
고 힘들어도 그렇게 함으로 인해서 그나마 나 같은 사람 이라도 있어서 애들이 여기라도 있어서 다행이라는 생 각도 가지니까 좋기도 하고. 내가 또 아들을 조금이라도 도와줄 수 있어서 좋다는 생각도 있고 그런 것도 있고 그 래요. (1차 개별면접, ID 04)

노년기 삶의 이유가 되는 손자녀 한편 일부 연구참여자는 손 자녀에게 심리적으로 의지하며, 손자녀의 존재를 노년기 삶 의 이유로 설명하였다. ID 07 연구참여자의 경우 젊은 시절부 터 힘든 일이 많았던 삶을 토로하며, 대리양육의 의무를 가지 고 손자녀를 양육하는 것이 자신의 삶을 지탱할 이유가 되었 다고 인식하고 있었다. 가족 및 지인들과 대화할 기회가 많지 않다고 지각하는 ID 08 연구참여자의 경우, 이야기 상대가 되 어주고 건강이 좋지 않았을 때의 필요를 돌보아주는 손자녀에 게 심리적, 신체적으로 의지하고 있는 모습을 드러냈다. 또한 손자녀를 돌봄으로 인해 본인 건강도 챙기고 더 오래 살아야 겠다는 의지를 갖게 하였다고 설명하였다. 비록 표면적으로는 조부모가 양육자로서의 역할을 수행하고 있으나, 정서적인 어 려움을 겪고 있거나 사회적 지지원이 부족한 경우, 손자녀가 조부모의 중요한 지지원의 역할을 하는 것으로 해석된다.

저것들 아니면 벌써 죽었을 것 같아. 왜냐하면 저것들 키 우는데 정신을 쏴서 내가 명을 사나보다 그러는 것 같아. 다 일찍 죽는다 그랬어요. 오십 먹으면 죽는다 그랬거든 요. (1차 개별면접, ID 07)

누구하고 애기할 사람이 있어요. 우리 저거하고만 애기하 지. 저거하고만 애기하지 누구하고 애기 할 사람 있어요. 며느리가 있다고 해서 애기를 하나. 아들이 있다고 해서 애기를 하나. 난 생전 그런 걸 몰라요. (중략) 지가 저렇게 들어와 앉아서 공부 하고. 할머니 옆에 앉아서 시중들고. 그게 제일 보람 있어요 나는. (1차 개별면접, ID 08)

\section{학령 초기 손자녀 대리양육에 대한 조부모의 인식 및 요구}

\section{학령 초기 양육자 역할에 대한 조부모의 인식}

연구참여자들은 학령 초기 아동의 발달을 위한 양육자로서의 적절한 역할에 대해 '잘 모르겠다'고 이야기하는 경우가 많았 다. 예컨대 ID 01 연구참여자의 경우 학령 초기 아동의 발달에 
어떤 것이 필요한지 본인이 잘 알지 못한다고 인식하며 답답 함을 느끼고 있었다. 또한 일부 연구참여자들은 학령 초기의 발달 과업 및 양육자의 역할에 대한 면접자의 질문에, 양육자 로서의 역할을 적성 및 특기를 찾고 키워주어야 하는 역할로 규정하였다. 즉, 학령 초기 양육자로서 조부모의 양육지식에 상당한 한계가 있음이 드러나고 있었다.

학교 가기 전에는 어린이집에서 종일반으로 지내고. 그 래서 그냥 그렇게 지내고. 아무래도 다른 애들 같이 해줘 야 하는 그런 것을 못해주니까 어떻게 해줘야 잘 해주는 지 그게 걱정이고 그래요. 뭐를 어떻게 해줘야 되는지 내 가 모르는 게 많으니까 그런 게 문제죠 뭐. (1차 개별면 접, ID 01)

글쎄 지가 미술을 하고 싶다는데, 미술학원을 보낼 수도 없고 그냥 그래서 미술도 학교에서 하고 그러니까 그냥 뭐야 저기한 거는 기초는 배우고 있는 것 같아요. (1차 개 별면접, ID 07)

대리양육의 어려움을 토로하며 손자녀의 친부모가 미래에 직접 아동을 양육할 가능성이 있다고 이야기한 일부 연구 참 여자들 또한, 양육자 역할이 필요한 아동의 발달적 측면을 어 렴풋이 인식하고 있었지만, 이에 적절히 대처할 방법을 알고 있지 못한다고 지각하고 있었고, 부모가 미래에 직접 아동을 양육하게 될 것이므로 조부모인 본인이 신경 쓰지 않고 있다 고 이야기하였다. 즉, 대리양육의 일시적 보호의 특성이 양육 행동에 반영되고 있다고 해석된다.

이제 조금 있으면 지 아빠 오니까 나는 아유... 상관 안한 다고. 그냥 지금도 생각하지를 않아요. (1차 개별면접, ID 07)

뭐 좀 할려다 보면 머리 아프다 그러고 울렁거린다 그러 고 이래. 그래서 그냥 자꾸 예는 다그치니까 안 되겠다... 그래서 냅둬버려. 개야 어차피 가면 또 거기서 그거 해야 되는데... 여기서 뭐 한글 또 알아가지고 괜히 그러다 보 면 역효과가 날 것 같아서 그냥 냅둬버려. (2차 개별면접, ID 04)

\section{학령 초기 손자녀의 발달에 대한 조부모의 인식}

일찍 철이 든 아동 연구참여자들은 손자녀가 자신의 마음을 잘 표현하지 않거나, 필요한 물건을 잘 사달라고 요구하지 않 는 등 일찍 철이 들었다고 인식하며, 이러한 손자녀의 특성에 대한 안타까운 마음을 표현하였다.

애도 남보다 일찍 철이 들어버린 거예요. 엄마가 나 나두 고, 삼촌한테 맡기고 도망갔다고 엄마가 나 안 찾는다고, 엄마 싫다고. (중략) 그리고 어디가 많이 아파도 혼자 울 음을 삼켜요. 아프다 소리를 안 해요. "왜 그러니?” 그러면, "할머니 나 많이 아프다고 애기하면 할머니 속상하니까." (1차 개별면접, ID 01)

가만히 보면 속은 찼는데 애기를 잘 안하는 거 같애. 뭔가 를 애기 하려다가도 "아니야." 이러고 안 해요. "아니야 애기 해도 돼." 그래도 "아니야. 안 할래." 그러고 말고. (1차 개별 면접, ID 02)

정서적 결핍감 및 또래 관계 문제 가능성 대다수의 연구참여 자들은 손자녀가 학교에 진학하면서 겪을 수 있는 부모의 부 재로 인한 정서적 결핍감 또는 위축감에 대해서 걱정하고 있 었고, 아동이 부모의 부재를 느낄 수 있는 상황을 가능한 한 피 하려고 한다고 설명하였다. 예컨대 ID 01 연구참여자 같은 경 우, 체육대회와 같은 부모가 참여하는 학교 행사에 참가했을 때 손자녀가 체육관 밖으로만 나가던 모습을 묘사하며, 그 뒤 로는 체육대회에 가지 못했다고 표현하였다.

체육대회 하는 걸 안 갔었어요. 한 번 갔다가. 학교 체육 관을 빌려가지고 하는데. 다른 애들은 엄마, 아빠, 할아 버지 해 가지고 다섯, 여섯 명씩 왔는데 애는 지 할아버 지 아파가지고 둘이 갔거든요, 달랑. 그러니까 애가 (중 략) 밖으로만 나가더라고. 운동장으로만 돌더라고요 애 가. 그래가지고 아차 싶어가지고 그 다음부터는 체육대 회는 일절 안 갔어요. 그 다음부터는 안 간 거예요. 못 간 거예요. (1차 개별면접, ID 01)

또한, 손자녀가 친구들과 사이좋게 지내고 있음을 묘사한 ID 05 및 ID 06 연구참여자를 제외한 다른 연구참여자들은 부 모의 부재로 인해 또래 간 다툼이 발생하거나 손자녀가 또래 괴롭힘의 대상이 될 가능성에 대해 인식하고 있었다. 또한 이 
러한 문제를 예방하기 위한 노력을 기울이고 있다고 설명하 였는데, 예컨대 다른 아동들에 비교해 '엄마 없는 아이들'처럼 보일 수 있다는 걱정으로 인해 손자녀의 위생 상태, 옷과 신발 등을 포함한 용모와 차림에 대해 더 민감하게 주의를 기울인 다고 하였다(ID 04). ID 07 연구참여자와 같은 경우에는, 특히 손자녀들의 부모가 행한 범법행위로 인해 또래로부터 손자녀 가 질문을 받는 등의 상황을 우려하여 손자녀들의 부모와 함 께 살지 못한다고 설명하였다.

애들 먹는 거, 입는 거 신경이 쓰이죠. 애들 엄마, 아빠 없 어서 저렇게 입고 다닌다고 할까봐. 그런 생각 안해야 되 는데 재들 엄마, 아빠 없어서 추레하다고 그 소리 듣고 다닐까봐 자꾸 그런 생각이 들어서 더 씻기고, 더 입히 고, 더 먹이고 하려고 그래. (1차 개별면접, ID 04)

만나기는 일주일에 한 번씩 만나기는 만나는데. 그렇죠 뭐. 그리고 또 만약에 이리 와서 같이 산다고 하더라도 애 들한테 지장이 많고 그러니까. (중략) 또 애들이 저 사람 이 아빠냐 물어볼 수도 있을 테고. 그러니까 모든 게 요건 이 맞지 않고 충격 받고 그래서. (2차 개별면접, ID 07)

아동의 발달적 문제 일부 연구참여자들은 손자녀가 보이고 있는 심리적, 행동적 문제에 대한 우려를 표현하였고 이러한 문제가 학교생활에 문제를 야기할 것을 걱정하고 있었다. 또 한 문제의 근원을 부모의 부재로 인한 상처 또는 결핍으로 인 식하며, 이러한 문제가 지속될 가능성에 대해 우려하였다. 그 러나 문제의 인식에도 불구하고, 손자녀에게 놀이치료를 받도 록 한 ID 01 연구참여자를 제외하고, 나머지 연구참여자들은 손자녀를 위한 치료의 필요성 인식은 나타내지 않았다. 예컨 대 ID 04 연구참여자의 경우, 손자녀의 문제를 설명하고 문제 로 인한 양육의 어려움을 표현하였으나, 치료가 필요할 가능 성에 대해서는 부정하였다.

자기 차례 되니까 두리번거리고 찾아요. 그러다가 그 때 가서 보고선 서로 마주쳐가지고 손을 흔들어 줬어요. 그 러니까 할아버지, 할머니 확인을 하고 거기에만 열중을 하더라고. 애가 그런 게 있죠. 아무래도 자기 나름대로 안 보이면 불안하죠. (1차 개별면접, ID 01)

핫초코를 겨울에 따끈따끈 타주거든. (중략) 그걸 주르 륵 농 뒤에 다 털어 부어 놓은 거야. 침대 머리맡에. 그게
죽 늘어서 말라 비틀어져 있고. 오죽하면 사진 찍어서 아 버지한테 보냈다니까. 사탕, 초콜릿 또 엉망으로 말도 못 하게 어질러 놓고. (중략) 애들이 정신이 이상한 애들이 아니냐...(중략) (선생님이) 정신과 치료를 받아야 된다는 둥 막 이런 소리, 저런 소리를 하는 거야 이제. 근데 그 선 생이 나는 평소에도 별로 마음에 안 들었어. (1차 개별면 접, ID 04)

한편 일부 연구 참여자들은 발달에 장기적으로 부정적인 영향을 미칠 가능성이 있는 손자녀들의 행동적 특성에 대해 묘사하였으나 이를 문제로 인식하고 있지는 않았다. ID 08 연 구참여자의 경우 손자녀가 친구들과 전혀 시간을 보내지 않고 할머니와만 시간을 보낸다고 보고하였다. 손자녀의 친구들이 놀러왔을 때 친구들이 몰래 인형을 갖고 간 경험을 이야기하 며, 손자녀가 또래와 어울리지 않도록 권하고 있다고 이야기 하였다.

안 놀아요. 애들이 여기 이사와가지고 이 밑에 애들이 다 섯, 여섯 명 있더라고요. 저 반에도 있고. 친구들이... 그 런데 '너희 집 놀러갈까?' 그러면 "오지 마. 우리 할머니 는 애들 오는 거 싫어하니까 오지마." 그런대요. 지가 그 래. 애들이 할머니 무서워서 안 놀러 온대. (중략) 그러니 까 나는 그런 걸 모르겠어요. 애들이 하도 쪼그만 것들이 그냥. 못되게 구니까. 웬만하면 안 사귀는 게 좋다 그러 니까는... 나는 안 사귀는 게 좋다고 그래요. (1차 개별면 접, ID 08)

\section{학령 초기 손자녀 대리양육의 요구들}

학교 생활 조력자에 대한 요구 연구참여자들은 공통적으로 학령 초기 손자녀들의 학교 공부를 지도하거나 숙제를 감독하 는 데 있어서 큰 어려움이 있다고 토로하였고, 이는 많은 경우 조부모로서 공부 지도에 필요한 다양한 한계, 특히 지식적 측 면에서의 한계를 경험하고 있는 것과 관련이 있었다. 손자녀 의 학교 공부를 도와주지 못하는 것은 양육자로서의 자괴감으 로도 이어졌다.

내가 아는 게 없으니까 '어떻게 제대로 가르치지' 라는 생각이 들더라고. 국어고 수학이고 보면 답안지가 다 있 잖아요. 그래서 그런 건 답안지 보고 하겠는데 영어는 배 운 게 없으니까. 아예 안 배워서 봐도 모르겠어서 그게 
제일 걱정이라... (1차 개별면접, ID 06)

나는 내가 배우질 못해서 그런지 우리 $\mathrm{OO}$ 이 공부하는 법만 가르쳐 주면. 나는 그런 거 밖에는 없어요. 네. 그렇 죠. 그런 거 밖에는 없어요. 그래서 어떤 적에는 '왜 내가 공부를 못 해가지고 이렇게 애 저거 하지를 못하나' 하 고... "(아이가)할머니 걱정하지마 내가 알아서 할테니 까." "알았어. 시끄러. 할머니가 공부 못해서 바보 짓 하 니까 그래. 내가 너한테 미안해서 그래." (1차 개별면접, ID 08)

또한 일부 연구참여자들의 진술에서는 학령 초기 아동을 양육하는 데 필요한 적절한 양육 기술이 부재함이 반영되었 다. 특히 손자녀가 방과 후 시간을 보내는 방식에 문제점이 있 음을 인식하고 있었으나, 이를 적절히 지도. 감독할 방법을 알 지 못하였다. 따라서 지속적으로 손자녀가 방과후 시간에 다 음날의 숙제와 준비물을 미리 준비하는 습관을 갖지 못하고, 불충분한 준비상태로 등교하는 생활이 이어지고 있었다.

공부라 하는 건 아예 집에서 책 한번을 안 들여다 봐. 아 무리 책을 봐라 해도 그냥 저거뿐이지 하지를 않아. 내가 또 귀찮아가지고 다그치고 뭐... 내가 말만 그래놓고 돌 아서 놓곤 잊어버려. 이제 왜 이렇게 정신이 없어서 깜빡 깜빡 잊어버려가지고, 혼내는 것도 정신이 있어야 혼을 내는데 말만 해놓고 잊어버려. 그러니까 안 되더라고. (2 차 개별면접, ID 04)

글쎄 그걸 모르겠어요. 거기서 (돌봄 교실) 지가 다 해놓 고 오는 때가 있고. 그러니까 지가 거기서 뭐 하라 그러 면 하는 건지 그거는 내가 안 봤으니까 모르는데 어떤 때 는 숙제를 다 했다고 그러고 그냥 안하고, 어떤 때는 이 런 저기를 가져오면 거기 이제 그 위에서 뭐뭐 해오라는 것을 그냥 놔두니까 안했잖아요. 안했으니까 아침에 내 가 책 챙기고 "학교 갈 거 다 준비됐니?" 그러면 그때서 바쁜 거야 이제. (1차 개별면접, ID 07)

학교 공부 지도의 한계는 연구참여자들이 인식하는 경제적 어려움과도 밀접하게 연관되었다. 모든 연구참여자들은 손자 녀들의 학교 공부를 위해서 방과후 교과 학습 및 예체능 교육 이 더 필요하다고 인식하고 있었으나 경제적 여유가 없는 것 이 원하는 대로 충분히 교육시키지 못하는 원인이라고 인식하
고 있었다. 손자녀의 교육을 경제적으로 지원해주는 것이 중 요한 양육자의 역할이라고 인식하고 있는 조부모일수록, 교육 을 위한 경제적 여유가 없는 것을 큰 마음의 부담으로 표현하 였다.

우리 손녀딸을 저 하고 싶은 대로 뒷바라지를 해주면 좋 겠는데 그걸 못해주니까 내가 그냥. 그냥 어쩔 때는 영어 공부 한 시간 씩이라도 영어공부 학원에 가서 하면 좋은 데 그걸 못해주니까 어떨 때는 속이 상해요. 내가 막 공 부하라고 야단하다가도 "할머니 내가 공부가 막히는 걸 어떻게 해요.” 그러면 그게 속이 상하는 거예요. (1차 개 별면접, ID 08)

연구참여자들은 학령 초기 아동 양육의 어려움, 특히 학교 공부 지도의 어려움 때문에 대신 공부를 지도해줄 수 있는 친 인척 및 교사 등 주변의 사회적 지지원에 의지해야 하는 상황 이라고 인식하고 있었다. 특히 손자녀의 이모, 삼촌, 사촌과 같 은 가까운 친인척에게 공부의 도움을 받을 수 있는 참여자들 에 비하여, 도움을 줄 수 있는 친인척이 없는 연구참여자들은 손자녀의 학교 교사, 돌봄 교실 교사, 학습지 교사를 공부 지도 를 위한 중요한 지지원으로 인식하고 있었다.

나 혼자서도 애를 키우는 것도 아니고 이모가 일주일이 면 두 번을 와요. 와서 이제 학교 공부를 도저히 나는 어 떻게 할 수가 없더라고요. 그전 같지가 않고 조금 어렵 고... 한글을 가르치는 것 까지는 괜찮은데 수학이나 이 런 것 까지는 도대체 나는 할 수가 없어서 이모가 와서 월, 화 해주고 금요일 날 와서 데려가서 있다가 또 데리 고 오고 그래요. 공부를 내가 가르칠 수가 없으니까. (1차 개별면접, ID 02)

뭐 하나를 작성하더라도 옛날에 배운 식이 있는데 그런 데 우리가 지금 이해를 많이 못하는 게 있죠. 근데 그런 거는 나이가 들면서 얼굴이 두꺼워져요. 젊은 사람들한 테 저기 그런 거하고 눈높이 그런 선생님 하는 받는 게 있거든요. 그럼 그런 선생님들한테 "내가 이거 하는 게 있는데 뭔지 모르겠는데 어떻게 해." 하면 선생님들이 친절하게 가르쳐 주셔서 해결이 돼. 아무래도 내가 그걸 못 따라가니까 어떨 때는 준비물 같은 걸 제대로 못해줄 때가 있지. 그러면 선생님한테 툭 까놓고 예기를 해야지 어떻게 해. (1차 개별면접, ID 03) 
그 중에서도 손자녀의 학교 교사는 학교 공부 지도 외에도 다양한 측면에서 조부모를 도와주는 역할을 감당해주고 있다 고 대부분의 연구참여자들에게 인식되고 있었다. 연구참여자 들은 손자녀들의 학교 교사들이, 학부모들이 일반적으로 감당 하는 학교에서의 봉사활동 및 부모참여 수업 등에서 아동의 가정상황을 이해하고 조부모가 참여하지 않도록 도와주고 있 다고 이야기하였다. 또한 일부 연구참여자들은 손자녀의 학교 생활을 조부모가 걱정하지 않도록 학교 교사가 정서적으로도 배려해주고 있다고 인식하고 있었다.

(학부모) 총회 같은 것은 안가요... (중략) 할머니가 힘드 니까 오기를 바라고 그러지 않으시죠. 그런 거는 젊은 엄 마들이 다하고 그런 거는 힘들다고 선생님도 못 오시게 하더라고. (2차 개별면접, ID 06)

선생님이 "어유 $\mathrm{OO}$ 이는 뭐 하나도 걸릴 게 없으니까 걱 정하지 말고 집에 가 계세요.” 그러더라고요. (중략) 네. 지가 다 알아서 하니까는 선생님도 뭐라고 할 말이 없다 그러더라고요. (2차 개별면접, ID 08)

양육 정보/교육 지식에 대한 요구 대부분의 연구 참여자들은 양육 지식 및 교육 정보 습득이 매우 필요한 부분이라고 여기 고 있었으며 대부분 주변의 지인들을 통해 비공식적인 방식으 로 양육지식 및 교육정보를 구하고 있었다.

주변 사람들 하고, 모르면 애 엄마들하고 연락하고. 주로 많이 오는 데가 여기 센터 같은 데. (중략) 그리고 헬스장 같은 데가 사람이 많이 오잖아요. (중략) 시장 같은 데 가 면 상인들도 알고하니까 그럼 사람들한테 여쭤보고. (1 차 개별면접, ID 01)

모르는 거 물어보니까 그 엄마들이 하는 거 다 가르쳐주 지요. 내가 모르는 거는... (중략) 그냥 뭐 일상적인 거지 요. 뭐라 그래야 되나? 책 같은 것도 엄마들한테 물어보 고 사주는 것도 있고... 그냥 애들이 숙제 뭐 준비물 해오 라 하면 모르는 게 있으면 그 엄마들이 가르쳐 주고 그러 지요... (중략) 그냥 엄마들하고 소통이 많아요. 젊은 엄 마들. (2차 개별면접, ID 06)

대다수의 연구 참여자들은 또한 본인의 양육 지식 및 정보 습득의 기회가 전반적으로 부족하다고 인식하였다. 그리고 그
러한 기회가 닿는다면 정보를 제공하는 모임에 적극적인 참여 의지가 있음을 표현하였다.

그냥 내 스스로 해결을 했지. 누구한테 갔다가, 친구를 만나면 이랬다 이야기 식으로 할 뿐이지. 젊은 엄마들, 애 키우는 엄마들한테나 통하는 말이지. 내가 지금 만나 는 사람은 다 내 또래잖아. 그 사람들한테 말해봤자 해당 이 하나도 없지. (1차 개별면접, ID 04)

내가 뭐를 모르니까. 이런 거는 좋다 하면 가서 배우고는 싶어요. 솔직히. 애들 크는 성장이라든가 교육에 대한 그 런. (중략) 그런데서 한다고 초청을 저기로 오면 가서 배 우고는 싶어요. 배워서 내가 $\mathrm{OO}$ 한테 가르치고 싶어요. 근데 지금 단계에서는 지금 내가 그런 단계를 하나도 모 르잖아요. 애들 다 큰 다음에 애를 키우니까 뭐가 좋고 어쩐 거는 모르니까. (1차 개별면접, ID 05)

그러나 정보 습득의 양 및 정보를 구하는 적극적 태도의 유 무는 연구참여자의 정서적 상태 및 사회적 지지망의 정도와 연관성을 나타내고 있는 것으로 보였다. 예컨대 ID 08 연구 참여자의 경우, 다른 사람과 이야기를 나누기 싫은 정서 상태 를 이야기하였으며, 다른 사람과 이야기를 나누지 않아 손자 녀의 학교 및 방과 후 활동에 대한 이야기 또한 주변 사람에 게 들은 바 없고, 주변에 양육을 도와줄 사람 또한 없다고 이 야기하였다. 선행 연구들은 대리양육 조부모들의 우울감(J.H. Bae, 2007; Kwon, 2000) 또는 사회적 지지망의 부족(O.-N. $\mathrm{Kim}, 2007)$ 을 보고하고 있는데, 이와 같은 조부모의 정서 상태 및 사회적 관계의 취약성이 학령 초기 손자녀를 양육하기 위 한 능력에도 직접적으로 영향을 미치고 있음을 알 수 있었다.

(학교생활에 대해서 들은 바가) 없어요. 누구 알아야 동 네 사람들하고 이야기를 하죠. (중략) 저는 누구하고 애 기도 하기 싫고 남하고도 만나기도 싫어요. 난 그러니깐 동기도 한번 안 만나고 친구도 안 만나고 그래요. (2차 개 별면접, ID 08)

정책적 지원에 대한 요구 연구 참여자들은 현재 정부기관 및 기타 복지기관에서 무료 급식, 돌봄교실, 주택지원 등의 다양 한 복지 혜택을 받고 있었다. 다수의 연구참여자들은 학교에 서 급식을 제공받고, 돌봄 교실에 참여할 수 있는 우리나라의 복지정책을 긍정적으로 평가하였고, 대리양육에 도움이 되는 
중요한 지지원으로 인식하였다.

내가 이번에 작은 애 학교를 가서 여러 가지를 봤을 때 '참 우리나라 좋아졌다. 복지혜택이 이 정도면 굉장히 좋 아졌다.'는 생각이 들더라고. 엄마, 아빠 애들 다 학교에 서 돌봐주지. 밥 먹여주지. (중략) 그렇게 해주는 나라가 얼마나 되겠나 싶더라니까. (1차 개별면접, ID 04)

그러나 복지혜택의 질과 양 또한 연구 참여자들마다 달라 복지혜택의 종류에 따른 경제적인 여건도 각기 다른 결과를 낳고 있었다. 특히 사회적 지지원의 차이에 따라 복지 혜택에 대한 정보 획득 및 실제 수혜 정도 또한 차이가 나타났는데, 예 컨대 연구 참여자들이 복지 헤택에 대한 정보원으로 가장 많 이 언급한 동사무소 직원을 통한 정보와 적극적인 도움의 정 도는 복지혜택 수혜에 큰 영향을 미치고 있었다.

막 울었더니 거기 (동사무소) 사람이 할머니 젊은 사람 도 둘 키우는 것이 힘든데 노인네가 둘 키우는 것은 정 말 장한 일이라고... 근데 어떻게 할 수가 없대요. 정부에 서 내려오는 거니... 그저 암만 백날 울어도 소용이 없고 어떻게 해. 집으로 와야지. 오려고 나오니까 그러더라고 직원이... 어쨌든 하여튼 자기가 최선으로 어떻게 하여튼 애기는 해보겠대요. (1차 개별면접, ID 07)

\section{손자녀 양육의 목표 및 희망}

\section{바람직한 인성을 가진 사회의 일원으로 성장}

연구참여자들은 손자녀가 '공부를 잘하고' 경제적으로 '여 유로운 생활'을 하기를 바라는 마음을 일부 표현하기도 하였 으나, 한 명도 빠짐없이, 무엇보다도 손자녀가 바람직한 인성 을 가지고 사회의 충실한 일원으로 성장하기 원하는 희망을 표현하였다. 이러한 희망은 손자녀가 타인에게 도움을 받고 자라난 것처럼 다른 사람에게도 도움을 줄 수 있는 사람으로 자라나기를 바라는 마음, 손자녀의 부모와 같은 삶을 살지 않 기를 바라는 마음과도 연관되었다.

올바르게만 커나간다면 더 이상 걱정할게 없잖아요. 마 음 삐뚤어지지 않고 그냥. 제가 항상 교회가면서 기도하 는 게 그거에요. 공부보다는... 할아버지한테도 그래요. 공부가 우선순위가 아니다. 공부는 다음번이고 우선은
애가 마음 곱게 자라는 거라고. 사회에서 인정받는 애로 자라는 거지. (1차 개별면접, ID 01)

그냥 착하게 잘 커줬으면 좋겠는데. 특별하게 바라는 건 없는데 지네 아빠, 엄마처럼만 안 살았으면 좋겠다 싶어 요. 그냥 평범하게 커서 착실하게 사회에 도움 되는 애들 로 컸으면 좋겠어. (1차 개별면접, ID 06)

\section{사랑이 채워지는 삶}

손자녀가 바른 인성을 가진 사회의 일원으로 살아가기를 바라 는 것 외에도, 대부분의 연구참여자들은 손자녀가 경험하고 있는 부모의 빈자리를 대신 채워주고 싶은 양육자로서의 희망 을 표현하였다. 현재로서는 양육자로서의 역할을 원하는 만큼 하고 있지 못하다고 인식하며 미안함과 아쉬움을 느끼고 있었 으며, 부모의 다양한 역할을 가능한 한 대신해주고 싶고, 가능 한 한 오래 돌봐주고 싶다고 이야기하였다.

우리 애들 위해서는 더 많이 해야 되는데, 내가 10 년만 젊었으면 하는 생각도 들고. 이 나이 됐으니 얼마나 더 돌봐주겠어. 내 힘도 빠지고. 그러니까 어떤 때는 '아... 10 년만 내가 더 젊었어도 애를 위해서 더 뭔가를 했을 것 같은데...' 이래요. (1차 개별면접, ID 03)

양육자로서 더 많은 역할을 해주고 싶은 마음과 더불어, 연 구참여자들은 손자녀가 경험한 부모 부재의 경험이 앞으로의 삶에서 보상되길 바라는 마음을 표현하였다. 손자녀가 일찍이 경험했다고 인식되는 '상처'를 더 이상 받지 않고, 다른 사람들 에게 사랑을 받고 자라날 수 있기를 소망하였다.

더 이상 애가 상처받는 일이 없으면 하는 거죠. 애가 어 려서 상처 받을 만큼 받았잖아요. (1차 개별면접, ID 01)

그저 남한테 지금처럼 남한테 귀여움 받고, 사랑 받고. 엄마, 아버지 사랑을 못 받고 컸잖아요. 여태. 사랑을 받 을 땐데, 엄마, 아버지를 보지 못하니까 못 봤잖아요. 여 태. 그게 너무 불쌍해서 엄마, 아버지 사랑 받는 저기에 지금처럼 사랑스럽게 진짜 호강 받고 그렇게 자랐으면 좋겠어요. 귀여움 받고. (1차 개별면접, ID 07) 


\section{논의 및 결론}

본 연구는 손자녀를 대리양육하는 조부모들의 양육경험을 심 층적으로 이해하기 위해 아동의 양육을 담당하고 있는 조모를 대상으로 질적 연구방법을 통해 그들의 경험을 살펴보고자 한 다. 본 연구를 통하여 대리양육 조부모가 자신들의 양육경험 에 어떠한 의미를 부여하는지 구체적으로 이해하고 실제적인 양육을 돕기 위한 제안을 하고자 한다. 질적 접근을 통해 추출 한 본 연구의 결과를 토대로 논의하고 결론을 내리면 다음과 같다.

첫째, 본 연구에 참가한 일부 대리양육 조모들은 손자녀 대 리양육의 원인이 자녀를 바람직하게 양육하지 못한 자신에게 도 있다는 책임감을 느끼고 있었으며, 자녀양육을 성공적으로 완수하지 못한 자신의 운명으로 수용하는 모습을 보였다. 자 녀의 인생이 자신이 자녀에게 부모역할을 잘 하지 못한 결과 라고 인식하여 책임감을 느끼고, 손자녀 대리양육을 통해 자 녀에게 보상하고자 하는 마음을 가지고 있었다. 그러나 자신 이 손자녀를 대리양육하게 된 것이 며느리 혹은 사위의 잘못 때문이라고 인식하고 있는 일부 조모들은 손자녀 대리양육 초 기에 손자녀 양육에 대한 분노 및 스트레스를 경험하였다고 말했다. 손자녀 대리양육에 대한 조모들의 초기 태도 차이는 조부모 및 친인척의 위탁양육에서 자발성 여부가 부모역할 스 트레스에 영향을 미친다는 연구결과(Yang, 2009)와 유사하다. 즉 손자녀를 대리양육 할 때 자발적인 동기에서 위탁양육 할 수록 조부모들이 부모역할을 쉽게 수용하고, 대리양육의 자발 성이 떨어지는 상황에서는 부모역할 수행에 대한 스트레스를 많이 느끼는 것으로 보인다.

둘째, 손자녀를 대리양육하고 있는 조모들은 양육을 통해 건강의 어려움과 돌봄의 어려움을 경험하고, 스트레스 등의 부정적 정서를 느끼는 등 다양한 어려움을 경험하고 있었다. 손자녀를 양육하는 조모의 생활만족도에서 건강상태는 중요 한 요인이 될 수 있으며(Chung \& Kim, 2010; Oh, 2007), 대리 양육위탁 조부모의 $49.3 \%$ 가 70-79세이고 80세 이상이 $13.6 \%$ 인 것을 고려할 때(MOHW, 2013) 고령의 대리양육위탁 조부 모가 느끼는 건강의 어려움이 심각한 문제가 될 수 있음을 알 수 있다. 대리양육 조부모가 신체적 건강의 어려움을 경험한 다는 연구결과(N.-R. Bae \& Park, 2013) 및 손자녀 양육을 전담 하고 있는 조부모들이 일반 노인들보다 주관적 건강상태를 나 쁘게 인식하고 있다는 연구결과(M.-Y. Lee, 2007)와 유사하게 본 연구에서도 조모들은 건강상의 어려움을 호소하였으며, 손 자녀를 대리양육하는 위탁양육 경험은 양육에 대한 책임을 자
녀와 공유할 수 없기 때문에 가사노동과 돌봄으로 인해 조모 들에게 더 큰 신체적인 건강의 어려움을 경험하게 하는 것을 알 수 있다. 특히 끊임없이 이루어지는 기초적인 돌봄과 이로 인한 가사노동 때문에 고령의 조모들은 체력의 한계를 느끼 고, 손자녀의 욕구를 충족시켜 주지 못하고 있다는 자책감 혹 은 이로 인한 스트레스를 경험하고 있었다. McGowen, Ladd와 Strom (2006)의 연구에서 양육권이 있는 조손가족보다 자녀 와 동거하며 공동양육하거나, 비동거형태로 양육하는 조부모 의 만족도가 더 높은 것으로 나타났으며, 국내연구(J.-H. Bae, 2007)에서도 주양육 조부모가 공동양육 조부모보다 우울 정 도가 높고 생활만족도가 낮은 것으로 나타났다.

이러한 결과들을 통해 주양육자로서의 역할이 조부모에게 신체적.정신적으로 부담이 되며 다양한 어려움을 경험하게 하 는 원인이 된다는 것을 알 수 있다. 주양육자의 스트레스가 아 동에게 미칠 수 있는 부정적인 영향에 대한 연구결과들(Barry, Dunlap, Cotten, Lochman \& Wells, 2005; H. M. Kim \& Doh, 2004)과 조손가족 조부모의 양육스트레스가 손자녀 우울에 영향을 미친다는 Y.-H. Lee와 Kim (2011)의 연구결과를 고려 할 때, 위탁 아동들의 건강한 성장과 발달을 위하여 주양육자 인 조부모의 스트레스와 어려움을 감소시킬 수 있는 방법을 모색하는 것이 중요하다는 것을 알 수 있다. 본 연구에 참가한 조모들과 같이 자녀의 도움 없이 손자녀를 양육하고 있는 위 탁 조부모들의 어려움을 이해하고, 이들의 양육에 대한 어려 움을 덜 수 있는 적극적인 개입이 필요하다는 것을 시사한다. 또한 방문 의료서비스와 건강증진 프로그램 지원을 통해 조부 모의 신체적·정신적 건강 증진을 위한 개입이 필요하다(M.-Y. Lee, 2008).

그러나 손자녀 양육에 대한 어려움에도 불구하고 손자녀 양육을 통해 조부모들이 즐거움과 만족감을 경험한다는 연구 결과들도 있다(Cox, 2009; K.-A. Park, 2007). 본 연구에서도 조 모들은 손자녀 양육을 통해서 기쁨과 보람을 느끼며, 노년의 삶에서 손자녀 양육이 삶의 이유가 된다고 인식하고 있었다. 이러한 본 연구의 결과는 젊은 세대와의 지속적인 접촉은 생 성감 형성을 증진하며(Bates \& Goodsell, 2013), 조부모 역할수 행은 생성감을 촉진할 수 있는 요소를 제공한다는 연구결과 (Hebbelthwaite \& Norris, 2011)와 유사한 맥락에서 이해할 수 있다. 노년기의 단조로운 일상에서 손자녀 양육은 즐거운 정 서를 느낄 수 있는 기회를 제공하고, 양육을 통해 생성감을 경 험할 수 있다는 것이다. 또한 양육을 통해 건강하게 성장하고 있는 손자녀를 지켜보는 것은 삶의 보람을 느끼는 요인이 되 고 있었다. 따라서 손자녀를 대리양육 하는 경험은 단편적으 
로 판단할 수 없는 다양한 감정적 스펙트럼을 경험하게 하는 것으로, 조모들은 감정의 명암을 함께 경험하고 있었다.

셋째, 본 연구에 참가한 조모들은 초등학교 1-3학년에 재 학 중인 손자녀를 대리양육하고 있으나 학령기에 진입한 손자 녀의 발달단계 및 발달단계에 적합한 부모역할 수행에 대한 인식이 부족했다. 조모들은 손자녀가 초등학교에 입학하기 전 까지 종일제 어린이집에서 보육하였고, 영유아에 대한 기본적 인 돌봄을 제공하는 것에 익숙하여 학령기의 발달단계에 대한 인식이 아직 부족해 보였다. 또한 문제행동을 보이고 있는 손 자녀에 대해 놀이치료와 같은 적극적인 개입을 하고 있는 조 모는 1 명뿐이며, 일부 조모들은 문제행동의 심각성을 우려하 고 있지만 치료적 접근과 전문가의 개입에 대해 거부적인 태 도를 보였다. 본 연구에 참가한 조모들은 부모교육을 통해 아 동의 발달단계에 대한 정보와 학령기 아동 지도방법 등의 지 식이 필요할 것으로 보였으며, 현재는 대부분의 조모들이 손 자녀와 관련한 정보를 이웃들 혹은 방문교사 등으로부터 비공 식적으로 습득하고 있었다.

또한 본 연구에 참가한 조모들의 손자녀들 대부분은 조부 모의 대리양육이 결정되기까지 부모의 불화, 부모의 죽음 및 경제적 어려움 등 부정적 경험을 하였으며, 조모들은 이로 인 해 손자녀가 일찍 철이 든 것에 대해 안타까움을 표현하였다. 본 연구에 참가한 조모들의 이러한 감정은 위탁 조부모들을 대 상으로 한 N.-R. Bae와 Park (2013)의 연구에서 손자녀에 대한 측은함으로 표현되어 유사한 맥락에서 이해할 수 있다. 이와 같이 일반 가정의 아동들보다 부정적 삶의 경험들을 많이 겪게 되는 위탁가정의 아동들이 건강하게 발달하기 위하여 조부모 들을 위한 부모교육을 통해 조부모들이 손자녀를 더욱 잘 이해 할 수 있도록 전문적인 지식을 제공할 필요가 있다. 비전문적 인 정보들을 접하게 되는 조부모들을 위해 적합한 부모교육 프 로그램을 개발하고 제공해야 하며, 손자녀의 발달단계 별로 도 움이 지속되도록 다발성 지원 및 조력 체계가 필요하다.

넷째, 손자녀가 학령기에 진입하면서 조모들은 학습지도의 어려움, 부모의 부재 및 또래관계에 대한 염려, 사교육에 따른 경제적 어려움 등을 경험하고 있었다. 학교생활을 시작하면서 학교적응에 대한 염려와 학습지도에 대한 한계를 인식하게 되 고, 학습적 지원을 필요로 하고 있었다. 보육기관에서 초등학 교로의 전환은 물리적 환경의 변화와 교수방법 및 하루일과의 변화에 적응해야 하는 부모와 아동 모두에게 어려운 과제이 다 (McIntyre, Eckert, Fiese, DiGennaro Reed, \& Wildenger, 2010; Wildenger \& McIntyre, 2010). 학령기 전환 자녀의 어머니 역할 경험에 대한 질적 연구(S. J. Kim et al., 2015)에서 어머니들은
학령기에 진입한 자녀에 대한 불안과 염려를 표현하였고, 이 로 인한 역할긴장에 대해 표현하였다. 위탁아동을 대리양육하 는 조부모에 대한 연구가 거의 없어서 비교하기 어렵지만, 어 머니들이 경험하는 이러한 불안, 염려, 그리고 역할긴장을 본 연구에 참가한 조모들도 유사하게 경험하고 있었다. 특히 조 모들이 학습지도에 대한 어려움을 크게 인식하고 있어서 이들 의 불안감을 감소시키고 부모의 학습지원을 받지 못하는 위탁 아동에 대한 체계적인 학습 지원이 필요하다는 것을 알 수 있 다. 또한 학령기에 진입한 손자녀의 학교생활에 대해 부모의 부재로 인한 낙인과 이로 인해 또래관계에서 소외감을 느끼게 될지도 모른다고 조모들은 염려하고 있었다. 본 연구의 결과 는 대리양육가정의 조부모가 사회적 고립이나 비정상가족으 로 인식되어 차별받을 가능성에 대해 불안해 한다는 연구결과 (N.-R. Bae \& Park, 2013)와 유사하다. 이러한 대리양육가정의 양육자들의 불안감을 감소시키기 위하여 이들을 위한 부모교 육 프로그램과 상담 프로그램이 체계화 되어 양육효능감을 높 일 수 있도록 지원이 필요하며, 학교 내에서 아동들이 따돌림 을 받지 않도록 사회적 지지가 이루어질 필요가 있다.

본 연구에 참가한 조모들은 학령 초기 손자녀에 대한 학습 지도에 부담감을 느끼고 있었으며, 학습지도에 대한 자신들의 한계를 극복하기 위하여 사교육 제공에 대한 필요성을 인식 하고 있었다. 그러나 사교육을 충분히 제공할 수 없는 경제적 상황 때문에 안타까움을 느끼고 있었다. 이와 같이 위탁 조부 모들이 경험하는 경제적 어려움은 선행연구(M.-Y. Lee, 2007; N.-R. Bae \& Park, 2013)와 유사하며, 조부모의 경제적 수준 은 양육스트레스 및 우울과 정적인 관계가 있으므로(FullerThomson et al., 1997; Kwon, 2000) 이들이 경험하는 경제적 어 려움은 조부모들의 양육스트레스 및 우울을 증진시키는 요인 이 될 수 있다. 또한 본 연구에 참가한 조모들이 받는 복지혜택 은 일관적이지 않았으며, 수급액이 가정마다 달라서 이에 대 한 행정적 개입이 시급하다는 것을 알 수 있었다. 국가적 지원 혹은 자선기관의 지원에 대해 조모들이 가진 정보가 다양하 고, 행정적인 절차에 대해 몰라서 지원을 늦게 받는 경우도 있 었다. 위탁가정 조부모들이 경험하는 경제적 어려움을 해소하 기 위하여 복지혜택이 균등하게 주어질 수 있도록 지원정책에 대한 홍보가 필요하며, 이를 위한 자조모임 등이 활성화될 필 요가 있다.

다섯째, 손자녀들을 대리양육하고 있는 조모들은 공통적으 로 손자녀가 바람직한 인성을 가진 사회의 일원으로 성장하 고, 부모의 부재로 인한 결핍이 채워지는 삶을 살아가기를 희 망하고 있었다. 이들이 조모들의 바람처럼 건강한 성인으로 
성장하기 위해서는 아동들이 가진 결핍을 채워줄 사회적 ·정 책적 지원이 필요하며, 대리양육하고 있는 조부모들을 위한 적극적 지원과 교육을 확대해 나갈 필요가 있다. 즉, 부모의 부 재와 다양한 부정적 사건들을 경험한 위탁 아동들이 건강한 사회구성원으로 성장할 수 있도록 양육에 대해 사회가 책임을 공유해야 하며, 구체적이고 체계적인 도움이 필요하다.

본 연구의 결과를 바탕으로 후속연구를 위한 제언과 본 연 구의 제한점을 논의하고자 한다. 먼저, 본 연구는 현재 초등학 교 저학년에 재학 중인 손자녀를 둔 조모를 연구대상으로 하 여 그들의 경험을 이해하고자 하였다. 후속 연구에서는 손자 녀의 성장에 따른 대리양육 조부모들의 심리적 변화를 심층적 으로 연구하기 위하여 중장기적 관점에서 추적조사가 필요하 다. 특히 초등학교 저학년부터 고학년을 거쳐 사춘기에 이르 기까지 대리양육 조부모들이 경험하는 어려움과 정서적 경험 의 변화를 추적하여 조부모 위탁가정을 위해 손자녀의 연령별 로 적합한 지원체계를 마련하는 것이 필요하다. 둘째, 후속 연 구에서는 조부모의 관점 뿐 아니라 조부모가 위탁양육하고 있 는 손자녀의 관점을 살펴보고, 이들의 경험과 요구를 이해하 여 총체적인 지원체계를 구축할 수 있도록 위탁양육을 받고 있는 손자녀 대상의 연구가 필요하다. 셋째, 본 연구는 약 4 개 월의 기간 동안 2 회의 개별면접을 통해 자료를 수집하였으나 조부모들이 학령 초기에 이른 손자녀를 대리양육하기까지 다 양한 가정 내 경험을 하였으며, 현재의 경험 또한 다양한 관점 에서 폭넓게 이해할 필요가 있음을 고려할 때, 후속 연구에서 는 면접 횟수 및 기간을 늘리거나 포커스 그룹 인터뷰 및 case study 등의 질적연구방법을 통해 이들의 경험을 보다 심층적 으로 이해할 필요가 있다. 또한 1 차 면접 시 연구참가자가 원 하는 곳에서 인터뷰를 진행하여 일부는 자택에서 인터뷰가 진 행되었고, 일부는 외부에서 인터뷰가 진행되어 가족사진 등 다양한 자료를 수집하는데 어려움이 있었다.

본 연구는 학령 초기 손자녀를 위탁양육 하고 있는 조모들 의 양육경험과 관련하여 부모역할의 의미와 어려움 그리고 양 육을 위해 필요한 지원 등에 대해 탐색해보았다는 데 의의가 있다. 사회적 지원, 가족지원, 신체적 건강이 좋을수록 조부모 양육만족도는 높아진다는 것을 고려할 때(Musil \& Standing, 2005; Waldrop \& Weber, 2001) 대리양육 조부모들을 위한 포 괄적인 지원서비스가 필요하다. 본 연구는 학령 초기 손자녀 를 둔 조부모교육 프로그램을 포함하여 친인척 위탁가정의 가 족관계 향상을 위한 프로그램의 개발 및 정책적 제안을 위한 기초 자료로서 활용될 수 있을 것이다.

\section{Acknowledgements}

This study was supported by the National Research Foundation of Korea grant funded by the Korean government (NRF2013S1A3A2055259).

\section{Notes}

This article was presented as a paper at the 2016 Annual Fall Conference of the Korean Association of Child Studies.

\section{Conflict of Interest}

No potential conflict of interest relevant to this article was reported.

\section{References}

\section{In English}

Bachman, H. J., \& Chase-Lansdale, P. L. (2005). Custodial grandmothers' physical, mental, and economic well-being: Comparison of primary caregivers from low-income neighborhoods. Family Relations, 54(4), 475-487. doi:10.1111/.1.1741-3729.2005.00334.x

Barry, T. D., Dunlap, S. T., Cotten, S. J., Lochman, J. E., \& Wells, K. C.(2005). The influence of maternal stress and distress on disruptive behavior problem in boys. Journal of the American Academy of Child and Adolescent Psychiatry, 44(3), 265-273. doi:10.1097/00004583-200503000-00011

Bates, J. S. \& Goodsell, T. L. (2013). Male kin relationships: Grandfathers, grandsons, and generativity. Marriage \& Family Review, 49(1), 26-50. doi:10.1080/01494929.2012. 728555

Brian, S. T. (2000). A cross-cultural study of the school performance of children bring raised by their grandparents (Doctoral dissertation). Retrieved from http://arizona.openrepository. com/arizona/bitstream/10150/289127/1/azu_td_9965933 sip1_m.pdf

Burnette, D. (2000). Latino grandparents rearing grandchildren with special needs: Effects on depressive symptomatology. Journal of Gerontological Social Work, 33(3), 1-16. doi:10.1300/J083v33n03_01

Cox, C. (2009). Custodial grandparents: Policies affecting care. Journal of Intergenerational Relationship, 7, 177-190. doi:10.1080/15350770902851221 
Creswell, J. W., \& Miller, D. L. (2000). Determining validity in qualitative inquiry. Theory into Practice, 39(3), 124-130. doi:10.1207/s15430421tip3903_2

Fuller-Thompson, E., Minkler, M., \& Driver, D. (1997). A profile of grandparents raising grandchildren in the United States. The Gerontologist, 37(3), 406-411. Retrieved from https:// gerontologist.oxfordjournals.org/content/37/3/406.full.pdf

Glaser, B. G., \& Strauss, A. L. (1967). The discovery of grounded theory: Strategies for qualitative research. Chicago: Aldine.

Hebbelthwaite, S., \& Norris, J. (2011). Expressions of generativity through family leisure: Experiences of grandparents and adult grandchildren. Family Relations, 60(1), 121-133. doi:10.1111/j.1741-3729.2010.00637.x

Kang, H., Chung, I. C., Chun, J., Nho, C., \& Woo, S. (2014). The outcomes of foster care in South Korea ten years after its foundation: A comparison with institutional care. Children and Youth Services Review, 39, 135-143. doi:10.1016/j.childyouth.2014.01.024

Maxwell, J. (2005). Qualitative research design: An interactive approach (2nd ed.). Thousand Oaks, CA: Sage.

McGowen, M. R., Ladd, L., \& Strom, R. D. (2006). Online assessment of grandmother experience in raising grandchildren. Educational Gerontology, 32(8), 669-684. doi:10.1080103601270500494048

McIntyre, L. L., Eckert, T. L., Fiese, B. H., DiGennaro Reed, F. D., \& Wildenger, L. K. (2010). Family concerns surrounding kindergarten transition: A comparison of students in special and general education. Early Childhood Education Journal, 38(4), 259-263. doi:10.1007/s10643-010-0416-y

Miles. B. M. \& Huberman, A. M. (1994). Qualitative data analysis. Thousand Oaks, CA: Sage.

Musil, C. M., \& Standing, T. (2005). Grandmothers' diaries: A glimpse at daily lives. International Journal of Aging and Human Development, 60(4), 317-329. doi:10.2190/LF1UJA0X-W7F9-341K

Neely-Barnes, S. L., Graff, J. C., \& Washington, G. (2010). The health-related quality of life of custodial grandparents. Health \& Social Work, 35(2), 87-97. doi:10.1093/ $\mathrm{hsw} / 35.2 .87$

Nomaguchi, K. M. (2012). Parenthood and psychological wellbeing: Clarifying the role of child age and parent-child relationship quality. Social Science Research, 41(2), 489-498. doi:10.1016/j.ssresearch.2011.08.001

Patton, M. (2002). Qualitative research and evaluation methods (2nd ed.). Thousands Oks, CA: Sage.

Ross, M. E. T., \& Aday, L. A. (2006). Stress and coping in African American grandparents who are raising their grandchildren. Journal of Family Issues, 27(7), 912-932. doi:10.1177/0192513X06287167

Sands, R. G. \& Goldberg-Glen, R. S. (2000). Factors associates with stress among grandparents raising their children. Family Relations, 49(1), 97-105. Retrieved from http:// www.jstor.org/stable/585706

Seidman, I. (1998). Interviewing as qualitative research: A guide for researchers in education and the social sciences. New York: Teachers College Press.

Waldrop, D., \& Weber, J (2001). From grandparent to caregiver: The stress and satisfaction of raising grandchildren. Families in Society: The Journal of Contemporary Social Services, 82(5), 461-472. doi:10.1606/1044-3894.177

Wildenger, L. K., \& McIntyre, L. L. (2010). Family concerns and involvement during kindergarten transition. Journal of Child and Family Studies, 20(4), 387-396. doi:10.1007/ s10826-010-9403-6

\section{In Korean}

Bae, J.-H. (2007). Factors affecting the psychological well-being of grandparents raising grandchildren: Focusing on the comparison between parenting grandparents and coparenting grandparent. Social Welfare Policy, 28, 67-94. doi:10.15855/swp.2007..28.67

Bae, N.-R., \& Park, C.-S. (2013). A qualitative study on the grandchildren rearing experiences of surrogate grandparents. Korean Journal of Family Welfare, 18(3), 333352. doi:10.13049/jofw.2013.18.3.333

Choi, H. (2006). Study on the determinant model of the relationship between custodial grandparents and custodial grandchildren in low socio-economic class. Journal of the Korean Gerontological Society, 26(3), 641-655. Retrieved from http://scholar.dkyobobook.co.kr/searchDetail. laf? barcode $=4010023796196$

Choi, H.-K. (2006). Social support for grandparent-headed families and its effects on grandparent caregivers' physical and mental health. Korea Journal of Population Studies, 29(2), 115-142. Retrieved from http://www.riss.kr/ link?id=A76122185

Chung, C. W., \& Kim, M. J. (2010). Grandmother's life satisfaction and influencing factors by grandparenting. Korean Journal of Women Health Nursing, 16(3), 288-296. doi:10.4069/kjwhn.2010.16.3.288

Doh, H.-S., Lee, H.-S., Kim, S.-H., Choi, M.-K., \& Lee, S. (2011). Human development and the family. Seoul: Gyomoonsa

Ha, M. J., \& Jang, Y. A. (2010). The effect of parenting efficacy, parenting stress on self-efficacy and daily stress among elementary school children. Korean Journal Community Living Science, 21(1), 33-51. Retrieved from http://www. riss.kr/link?id=A82263927

Jang, H.-S., \& Kim, Y.-J. (2008). A study on experience of old adults fostering grandchildren in rural areas: Focused on 
old adults in grandparents-grandchildren family. Journal of Welfare for the Aged, 40, 7-30. Retrieved from http://www. riss.kr/link?id=A75108888

Kim, H. M., \& Doh, H.-S. (2004). Maternal parenting stress, efficacy, and behavior: Relations to children's social competence. Korean Journal of Child Studies, 25(6), 279298. Retrieved from http://childstudies.org/upload/ pdf/31200981.pdf

Kim, H.-S. (2009). The fostering experience of custodial grandmother in low-income grandparent-grandchild family. Journal of Welfare for the Aged, 43, 61-92. Retrieved from http://www.riss.kr/link?id=A82603392

Kim, M. Y., \& Yoon, H. (2015). Grandparent-headed families in poverty: A qualitative approach focusing on family roles. Journal of the Korean Society of Child Welfare, 50, 145-176. Retrieved from http://www.riss.kr/link?id=A100682205

Kim, O.-N. (2007). Caregiving burden and rewards for the grandparents raising grandchildren. Korean Journal of Research in Gerontology, 16, 59-84. Retrieved from http:// www.riss.kr/link?id=A75217588

Kim, S. J., Song, S.-M., Doh, H.-S., Shin, N., Kim, M.-J., \& Kim, E. H. (2015). A qualitative study to the mother's role experiences during their child's transition from early childhood to middle childhood. Korean Journal of Child Studies, 36(2), 111-130. Retrieved from http://www.riss.kr/ link?id=A100494428

Kim, S. K., Kim, H. Y., \& Choi, H. M. (2009). Child Welfare. Paju: Yangseowon.

Kim, W., \& Jeon, J. (2010). Research trends concerning grandparents and grandchildren in Korean journals 1991 2000. The Korean Journal of Women Psychology, 15(4), 653-671. Retrieved from http://www.riss.kr/ link?id=A100632923

Kim, Y.-M., Kim, M.-H., \& Jung, Y.-J. (2008). An approach based on grounded theory about the care-giving experience of custodial grandparents. Korean Journal of Social Welfare Studies, 38, 123-163. Retrieved from http://www.riss.kr/ link?id=A75627261

Kwon, I. S. (2000). The relationship between the burden and the social support of grandmothers caring their grandchildren. Child Health Nursing Research, 6(2), 212-223. Retrieved from http://www.riss.kr/link?id=A77039629

Lee, J.-Y., Kim, W.-K., \& Chung, K.-M. (2009). The study of parenting stress, social support, coping, parental behavior in partial caregiving-grandmothers: Comparing with caregiving-mothers. Journal of the Korean Gerontological Society, 29(2), 441-458. Retrieved from http://admission. sangji.ac.kr/common/downLoad.action?siteId=walfare\&file Seq $=375064$

Lee, M.-Y. (2007). Process of forming grandparent raising grandchildren and their living conditions. The Journal of Public Welfare Administration, 17(1), 203-230. Retrieved from http://www.riss.kr/link?id=A75057095

Lee, M.-Y. (2008). A study on parenting stress of grandparent as a caregiver family. Journal of Social Welfare Development, 14(4), 327-353. Retrieved from http://www.riss.kr/ link?id=A75202043

Lee, Y.-H., \& Kim, D.-K. (2011). A study on relation between grandparent parenting stress and grandchildren depression, and mediation effect of the grandparent parenting attitude: Testing a developmental stages. Korean Journal of Youth Welfare, 13(2), 1-22. Retrieved from http://210.101.116.28/W_files/kiss10/78500356_pv.pdf

Ministry of Gender Equality and Family. (2007). A survey and study on the support plans for grandparent-grandson family (Report No. 2007-54). Retrieved from http://www.mogef.go.kr/

Ministry of Health and Welfare. (2013). 2013 child survey (Report No. 2013-92). Retrievd from https://www.kihasa.re.kr/ common/filedown.do?seq=16664

Oh, J. (2007). A structural model on the quality of life of grandmothers caring for their grandchildren. Child Health Nursing Research, 13(2), 201-211. Retrieved from http:// www.riss.kr/link?id=A77039812

Ok, K.-H. (2005). Grandparents raising grandchildren. Journal of Korean Management Association, 23(3), 103-114. Retrieved from http://www.riss.kr/link?id=A100455051

Park, C.-K. (2002). A study on family function of grandparent-child families in a rural area (Master's thesis). Retrieved from http://www.riss.kr/link?id=T8952592

Park, K.-A. (2007). A study of how social support affects rewards for grandparents who raise their grandchildren. Korean Journal of Family Welfare, 12(3), 25-45. Retrieved from http://www.riss.kr/link?id=A5080980

Seo, H.-L. \& Kim, Y.-H. (2010). A strengths-based group program for grandparents raising their grandchildren: Development and education. Journal of Welfare for the Aged, 47, 161-186. Retrieved from http://www.riss.kr/link?id=A77041055

Song, J. A. (2013). Child welfare: Understanding and practice. Paju: Yangseowon. Retrieved from http://www.riss.kr/ link?id=M13307283

Statistics Korea. (2014). A survey on the estimation of future household. Retrieved from http://www.kostat.go.kr/

Yang, S.-Y. (2009). Influence of the kinship foster family's psychological nurturing circumstances on children's problem behavior. Korean Journal of Family Welfare, 26(8), 193-224. Retrieved from http://www.riss.kr/link?id=A76551940 


\section{ORCID}

Seung-Min Song Woon Kyung Lee Yoon Hyung Lee Hyunah Kang
Eun Hye Kim

Hara Kang

http://orcid.org/0000-0002-8931-8327

http://orcid.org/0000-0002-2221-1787

http://orcid.org/0000-0002-8882-7605

http://orcid.org/0000-0001-6831-2252 http://orcid.org/0000-0002-0292-6830

http://orcid.org/0000-0001-7181-6726

Received December 31, 2016

Revision received January 31, 2017

Accepted February 9, 2017 